\title{
ХАРАКТЕРИСТИКА ЯКІСНОГО СКЛАДУ МОЛОКА КОРІВ УКРАїНСЬКОї БУРОї МОЛОЧНОї ПОРОДИ
}

\author{
Чернявська Тетяна Олексіївна \\ кандидат сільськогосподарських наук, доцент \\ Сумський національний аграрний університет \\ ORCID: 0000-0003-1296-5013 \\ E-mail: chernyvska9753@ukr.net
}

Проаналізовані літературні джерела з вивчення породних особливостей складових молока корів. Досліджені породні особливості вмісту окремих складових молока. Важливим показником, який характеризує якість молока є кількість соматичних клітин в молоці. Доведено, що цей показник є достовірним показником захворювання корів на субклінічний мастит. Це обумовлює, для підвищення конкурентоспроможності молочного скотарства впровадження регулярного моніторингу якісних показників молока. Першочерговим завданням є оцінка тварин вітчизняних порід. Це пояснюється не великою кількістю досліджень. Вирішення цього питання обумовило проведення досліджень на поголів"ї української бурої молочної породи, яке утримується в Державному Підприємстві «Дослідне Господарство агрофрірма «Надія» Інституту сільського господарства Північного Сходу Національної академії аграрних наук України» Роменського району. Визначення вміст складових молока проводили у випробувальному центрі інституту тваринництва НААН України на обладнанні фрірми Bentley. Mu досліджували біохімічний склад молока корів і встановили, що тварини української бурої молочної породи мають достатній вміст жиру та білка в молоці. Встановлена залежність вмісту складових молока від віку тварин. Повновікові тварини переважали за вмістом білка, казеїну, сухої речовини та сухого знежиреного молочного залишку первісток. Середній вміст соматичних клітин в молоці відповідав фрізіологічній нормі. Встановлено, що з збільшенням віком у корів збільшується вміст соматичних клітин в молоці. Між окремими якісними показниками молока виявлений зв'язок різного напрямку та рівня достовірності. Позитивний зв'язок встановлений між вмістом в молоці жиру та білка, жиру та сухої речовини, білка та казеїну, білка та сухого знежиреного молочного залишку. також встановлено, що у повновікових тварин сила зв'язку збільшується. Встановлений достовірний негативний кореляційний зв'язок між кількістю соматичних клітин у молоці та вмістом сухого знежиреного молочного залишку і лактози. Подальше вдосконалення української бурої молочної породи повинно бути направлене на підтримання та покращення якісного складу молока.

Ключові слова: молоко, порода, кореляція, вміст жиру, вміст білку, соматичні клітини.

DOI: https://doi.org/10.32845/bsnau.lvst.2020.3.14

В останні роки до якості молока приділяють все більше уваги, як виробники молочної сировини, так і її переробники. Це пояснюється тим, що поряд із нарощуванням виробництва продукції, саме її якість забезпечує продовольчу безпеку держави та стабільне постачання населення молочними продуктами $[8,9,10]$.

Молочні породи світу та України зокрема характеризуються високою молочною продуктивністю. Особливо це стосується голштинської, швіцької, айрширської, української чорно-рябої молочної, української червоно-рябої молочної та інших порід [14]. Та науковці давно стверджують, що покращуючи величину надою необхідно звертати увагу на вміст компонентів молока, а саме жиру та білка. Доведено, що якісні показники суттєво залежать від породи корів. Також походження тварин впливає на технологічні властивості молока $[13,15,19,20]$. Тварини різних порід суттєво відрізняються таким характеристиками, як вміст жиру та білка в молоці [3]. Саме тому науковці вважають, що хімічний склад молока $€$ одним із найважливіших інструментів економічного стимулу розвитку молочної галузі [17]. Evans K. зі співавторами [15] вважають, що на склад молока впливає не лише порода, ай умовна кровність тварин. M. De Marchi [16] робить висновок, що між такими породами, як голштинська, швіцька, симентальська існує вірогідна різниця за вмістом жиру та білка в молоці. Такий метод схрещування порід також впливає на показники продуктивності та технологічну якість молока тварин першого покоління [18].

В Україні за останні тридцять років створено такі мо-

лочні породи як українських червоно-ряба, чорно-ряба, червона, бура молочні породи. Ці породи характеризуються високою молочною продуктивністю та добрими якісними характеристикам молока. Річні надої корів молочних порід становлять 4000-6000 кг з вмістом жиру в молоці 3,6-4,1\% і білка - 3,2-3,7 \%. Вміст жиру і білка в молоці різних порід неоднаковий. У порід створених на основі голштинської породи - (в середньому) 3,68 \% жиру, 3,31 \% білка; симентальська -3,91 і 3,48; на основі швіцької породи - 3,75 і 3,41; червона степова - 3,73 і 3,32; лебединській - 3,90 і 3,56 \%. У молоці айрширської та джерсейської порід при надоях 3500-4000 кг молока вміст жиру та білка в молоці досягає відповідно 5,0-6,5 та $3,9-4,3 \%[3,4,12,14,15]$.

Вітчизняні науковці стверджують, що якісні показники молочної продуктивності тварин української бурої молочної породи мають високі значення: вміст жиру в молоці 3,98 \%; білка - 3,55 \%; казеїну - 3,31 \% [5, 6, 7, 12]. Порівнюючи вміст жиру в молоці українських чорно-рябої та бурої молочних порід, встановлено, що вміст жиру в молоці у тварин української бурої молочної породи був вищий на $0,16 \%$. При цьому тварини української бурої молочної породи поступалися за вмістом білка в молоці тваринам української чорно-рябої молочної породи на 0,05 \% [1, 7]. Науковцями встановлено, що протягом лактації жирність молока у корів чорно-рябої породи змінюється. Від початку лактації до її закінчення показник зазнає зміни від 3,70 \% до 3,85 \% [2].

Тому актуальним є дослідження хімічного складу мо- 
лока корів нових вітчизняних порід. Метою роботи - $€$ виявити породні особливості якості молока корів української бурої молочної породи. Для досягнення поставленої мети необхідно вирішити наступні завдання: дослідити вміст окремих компонентів молока; встановити вплив віку тварин на вміст окремих складових молока, дослідити наявність зв'язку між вмістом окремих компонентів молока.

Матеріали та методи досліджень. Для виконання поставленої мети, проведені в державному племінному заводі ДП «Дослідне господарство агрофрірма «Надія» Інституту сільського господарства Північного Сходу Національної академії аграрних наук України», Роменського району на 70 тваринах української бурої молочної породи. Дослідження проводились за умови однакової годівлі на рівні 45 ц к.о./рік. Молочну продуктивність оцінювали шляхом щомісячних контрольних доїнь з відбором проб молока. Визначення вміст складових молока проводили у випробувальному центрі інституту тваринництва НААН України на обладнанні фірми Bentley.
Досліджували відсоток жиру, відсоток білку, в т.ч. казеїну, відсоток сухої речовини, сухого знежиреного залишку, вміст соматичних клітин. Біометричну обробку результатів проводили за методикою М. О. Плохінського, з використанням програмного забезпечення Statistica 6.0 [11].

Результати досліджень. В результаті проведених досліджень встановлено, що рівень надої корів української бурої молочної породи були не високі і по першій лактації складали 3500 кг, а по третій - 3950 кг. відповідно до поставленого завдання нами був проаналізований біохімічний склад молока корів первісток та повновікових корів. Відповідно до стандарту породи вміст жиру в молоці у корів української бурої молочної породи повинен бути не меншу $3,8 \%$, а білка $3,3 \%$.

В результаті проведених досліджень виявлено, що первістки мали високі показники вмісту жиру - 3,95 \% та білка - 3,20 \% в молоці. При цьому у повновікових тварин вміст жиру був вищий $-4,04$ \%, а білка - 3,19 \% (табл. 1).

Таблиця 1 - Якісні показники первісток та повновікових корів

\begin{tabular}{|l|c|c|}
\hline \multicolumn{1}{|c|}{ Показники } & Корови-первістки & Повновікові тварини \\
\hline Вміст: & & $4,04 \pm 0,02$ \\
\hline жиру в молоці, \% & $3,95 \pm 0,02^{*}$ & $3,19 \pm 0,01$ \\
\hline білка в молоці, \% & $3,20 \pm 0,02$ & $3,00 \pm 0,03$ \\
\hline в т.ч. казеїну, \% & $2,99 \pm 0,03$ & $4,70 \pm 0,01$ \\
\hline лактози, \% & $4,71 \pm 0,01$ & $13,2 \pm 0,05$ \\
\hline сухої речовини,\% & $13,1 \pm 0,06$ & $9,16 \pm 0,02$ \\
\hline сухого знежиреного молочного залишку,\% & $9,15 \pm 0,02$ & $120,6 \pm 34,1$ \\
\hline Соматичних клітин & $97,0 \pm 21,4$ & \\
\hline
\end{tabular}

$$
\text { Примітка: * - } P<0,05 \text {; *** } P<0,001 \text { - порівняння до повновікових тварин }
$$

Достовірна різниця між якісними показниками молока між повновіковими тваринами та первістками встановлена лише за вмістом жиру в молоці. За іншими показниками різниця була несуттєвою.
Важливим питанням для вивчення є встановлення наявності зв'язку між окремими якісними показниками молока. Нами виявлено наявність кореляції між окремими якісними показниками молока (табл. 2).

Таблиця 2 - Кореляція між якісними показниками молочної nродуктивності, $r \pm m_{r}$

\begin{tabular}{|c|c|c|}
\hline Поєднання & Корови-первістки $n=25$ & Повновікові тварини $\mathrm{n}=45$ \\
\hline Жир х білок & $0,25 \pm 0,07^{*}$ & $0,29 \pm 0,05^{*}$ \\
\hline Жир х казеїн & $0,19 \pm 0,09^{*}$ & $0,23 \pm 0,07^{*}$ \\
\hline Жир х суха речовина & $0,91 \pm 0,01^{\star * *}$ & $0,94 \pm 0,02^{\star * *}$ \\
\hline Жир х СЗМЗ & $0,05 \pm 0,08$ & $0,02 \pm 0,04$ \\
\hline Білок x казеїн & $0,99 \pm 0,01^{* * *}$ & $0,99 \pm 0,01^{* * *}$ \\
\hline Білок $\mathrm{x}$ суха речовина & $0,41 \pm 0,07^{* * *}$ & $0,48 \pm 0,07^{* * *}$ \\
\hline Білок x С3М3 & $0,54 \pm 0,04^{* * *}$ & $0,56 \pm 0,02^{* * *}$ \\
\hline Вміст соматичних клітин х жир & $0,05 \pm 0,11$ & $0,04 \pm 0,07$ \\
\hline Вміст соматичних клітин х білок & $0,25 \pm 0,09^{*}$ & $0,19 \pm 0,05^{* *}$ \\
\hline Вміст соматичних клітин х суха речовина & $-0,08 \pm 0,07$ & $-0,12 \pm 0,05$ \\
\hline Вміст соматичних клітин х С3МЗ & $-0,25 \pm 0,09^{*}$ & $-0,32 \pm 0,13^{*}$ \\
\hline Вміст соматичних клітин х лактоза & $-0,41 \pm 0,08^{*}$ & $-0,35 \pm 0,13^{* *}$ \\
\hline
\end{tabular}

Встановлено, що коесіцієнти кореляції між вмістом жиру та білка в молоці, сухої речовини та сухого знежиреного молочного залишку позитивні та вірогідні. Негативні достовірні коефіцієнти кореляції встановлені між вмістом соматичних клітин в молоці та вмістом сухої речовини, сухого знежиреного молочного залишку та лактози. Отже ми можемо стверджувати, що при збільшенні вмісту соматичних клітин в молоці, а значить і наявність у корів маститу, в молоці у них зменшується вміст лактози, сухого знежиреного молочного залишку та сухої речовини. Тому в господарствах з розведення української бурої молочної породи необхідно приділяти увагу щодо виявлення та профілактики субклінічних маститів, що дозволить підвищити вміст складових молока. Важливим $є$ те, що вмісту лактози в молоці може слугувати відносним показником, який вказує на захворюваність корів маститом. Якщо вміст в молоці лактози зменшиться нижче 4,7\% то у цієї тварини можна підозрювати наявність субклінічного мастити. Це підтверджується не тільки нашими дослідженнями, а й інших дослідників [1, 7]. Також нами встановлено, що тварини української бурої молочної породи мали достатній вміст складових молока. Ці результати співпадають з іншими науковцями $[5,6]$. Одним із важливих залишається питання вмісту соматичних клітин в молоці. 3 віком тварин цей показник дещо збільшився, проте був фрізіологічно нормальним. Це 
підтверджує і Братушка Р. В. зі співавторами [1], який стверджує, що з збільшенням віку у корів в молоці підвищується вміст соматичних клітин (на 197\%).

Селекціонери зазначають, що важливо знати ступінь і напрямок зв'язку між окремими показниками молочної продуктивності. Це покращити селекційне удосконалення порід [1, 7].

Висновки. Тваринам української бурої молочної по- роди характерні високі показники якісних характеристик молочної продуктивності. Вміст жиру та білка в молоці відповідали породним вимогам. В результаті проведених досліджень встановлено, що якісний склад молока не суттєво залежить від віку тварин. 3 віком у тварин в молоці вірогідно збільшується лише вміст жиру на 0,09 \%. Вміст інших складових молока з віком майже не змінюється. Встановлені різні за напрямком та силою взаємозв'язки - від низьких від'ємних до високих позитивних.

\section{Список використаної літератури:}

1. Братушка Р. В., Скляренко Ю. І., Чернявська Т. О. Якісний склад молока корів української бурої молочної породи та сумського внутрішньопородного типу української чорно-рябої молочної породи. Проблеми зооінженерії та ветеринарної медицини. Серія: Сільськогосподарські науки. Харків, 2007. Вип. 22, Ч. 1, Т. 1. С. 249-253.

2. Остроумова Т. А., Иванов И. В. Влияние пород скота на состав молока и производство сыра. Техника и технология пищевых производств. 2009. №3. С. 55-63.

3. Полєва І. О. Порівняльна характеристика амінокислотного складу молока з різними технологічними характеристиками. Науково-технічний бюлетень IT НААН. 2018. № 119. С.122-128.

4. Приходько М. Ф. Оцінка продуктивності та технологічних властивостей молока новостворених порід і типів худоби північно-східного регіону України : автореф. дис. ... канд. с.-г. наук : 06.02.04 Херсон, 2009. 22 с.

5. Скляренко Ю. І., Чернявська Т. О., Бондарчук Л. В. Дослідження якісного складу молока корів української бурої молочної породи. Розведення і генетика тварин : між від. Темат. Наук. Зб. Київ : Аграрна наука, 2015. Вип. 53.С. 185 - 190.

6. Скляренко Ю. І. Особливості молочної продуктивності корів української бурої молочної породи та вплив генотипових і паратипових факторів на ї̈ формування. Наук. Віс.ЛНУВМБ ім. С. З. Гжицького : «Сільськогосподарські науки», 2018. 20 № 89. C. 8-16. doi 10/32718/nvlvet8901

7. Скляренко Ю. І., Чернявська Т. О. Зміни вмісту складових молока при захворюванні корів на мастит. Вісник Сумського національного аграрного університету. Серія: Тваринництво. Суми, 2013. № 1(22). С. 66-68.

8. Смоляр В. І. Комплекс заходів з підвищення якості молока. Вісник Дніпропетровського ДАУ, 2011. № 2. С. 151-155.

9. Ткачук В. П. Молочна продуктивність великої рогатої худоби та фактори, що її визначають. Технологія виробництва і переробки продукції тваринництва : 2011. Вип. 6. С. 38- 41.

10. Филь С. І., Федорович Є. І., Боднар П. В. Молочна продуктивність корів-дочок різних бугаїв-плідників. Наук. Bic.ЛНУВМБ ім. С. З. Гжицького : «Сільськогосподарські науки», 2018. Т. 21 № 90. С. 68-75. doi.org/10.32718/nvlvet-a9012

11. Царенко О. М., Злобін Ю. А., Скляр В. Г., Панченко С. М. Комп'ютерні методи в сільському господарстві та біології: навчальний посібник. Суми : Вид-во «Університетська книга», 2000. 203 с.

12. Чумель Р. А. Генетико-біохімічні та продуктивні особливості худоби північно-східного регіону України : авторефр. дис. .... канд. с.-г. наук : 03.00.15. Чубинське, 2004. 21 с.

13. Bras. R. Milk quality of Jersey cows kept on winter pasture supplemented or not with concentrate. Revista Brasileira de Zootecnia. 2009. Vol.38. P. 1983-1988. doi.org/10.1590/S1516-35982009001000018.

14. Dobson H., Smith R.F., Royal M.D., Knight C.H., Sheldon I.M. The high producing dairy cow and its reproductive performance. Reprod Domest Anim. 2007. Vol 42. P. 17-23. doi: 10.1111/j.1439-0531.2007.00906.x

15. Evans K., Rawlynce C., Joshua O. Amimo and Fidalis D. N. Mujibi. Milk Composition for Admixed Dairy Cattle in Tanzania. Frontiers in Genetics. 2018. Vol. 9. P. 1-12.doi.org/10.3389/fgene.2018.00142.

16. Marchi M., Bittante G., Dal Zotto R., Dalvit C., Cassandro M. Effect of Holstein Friesian and Brown Swiss breeds on quality of milk and cheese. Journal of Dairy Science. 2008. Vol. 91(10) P. 4092-4102. doi: 10.3168/jds.2007-0788.

17. Marchi M., Dal Zotto R., Cassandro M.'. Bittante G. Milk Coagulation Ability of Five Dairy Cattle Breeds. Journal of Dairy Science. Vol. 90. P. 3986-3992. https://doi.org/10.3168/ids.2006-627.

18. Puppel K., Bogusz E., Gołębiewski M. Effect of Dairy Cow Crossbreeding on Selected Performance Traits and Quality of Milk in First Generation Crossbreds. Journal of Food Science. Vol. 83. P. 229-237. https://doi.org/10.1111/1750-3841.13988

19. Stocco G., Cipolat-Gotet C., Bobbo T., Cecchinato A. Breed of cow and herd productivity affect milk composition and modeling of coagulation, curd firming, and syneresis. Journal of Dairy Science. 2017. Vol. 100. P. 129-145. doi.org/10.3168/jds.201611662

20. Yang T. X., Li H., Wang F., Liu X. L., . Li Q. Y Effect of Cattle Breeds on Milk Composition and Technological Characteristics in China. Asian-Australas J Anim Sci. 2013. Vol. 26(6) P. 896-904. doi: 10.5713/ajas.2012.12677.

\section{References:}

1. Bratushka, R. V., Sklyarenko, Yu. I. and Chernyavska, T. O., 2007. Yakisnij sklad moloka koriv ukrayinskoyi buroyi molochnoyi porodi ta sumskogo vnutrishnoporodnogo tipu ukrayinskoyi chorno-ryaboyi molochnoyi porodi [Qualitative composition of milk of cows of the Ukrainian brown dairy breed and Sumy intrabreed type of the Ukrainian black-and-white dairy breed]. Problemi zooinzheneriyi ta veterinarnoyi medicini. Seriya: Silskogospodarski nauki, issue 22, pp. 249-253.

2. Ostroumova, T. A. and Ivanov, I. V., 2009. Vliyanie porod skota na sostav moloka i proizvodstvo syra [Influence of livestock breeds on milk composition and cheese production]. Tehnika i tehnologiya pishevyh proizvodstv, issue 3, pp. 55-63. 
3. Polyeva, I. O., Dolgay, M. M., Kalashnikov, V. O. and Kurepin, O. O., 2018. Porivnyalna harakteristika aminokislotnogo skladu moloka z riznimi tehnologichnimi harakteristikami [Comparative characteristics of the amino acid composition of milk with different technological characteristics]. Naukovo-tehnichnij byuleten IT NAAN, issue 119, pp.122-128.

4. Prihodko, M. F., 2009. Estimation of productivity and technological properties of milk of newly created breeds and types of cattle of the northeastern region of Ukraine. Abstract of Ph. D. dissertation. Herson.

5. Sklyarenko, Yu. I., Chernyavska, T. O. and Bondarchuk, L. V., 2015. Doslidzhennya yakisnogo skladu moloka koriv ukrayinskoyi buroyi molochnoyi porodi [Research of qualitative composition of milk of cows of the Ukrainian brown dairy breed]. Rozvedennya i genetika tvarin, issue 53, pp. $185-190$.

6. Sklyarenko, Yu. I., 2018. Osoblivosti molochnoyi produktivnosti koriv ukrayinskoyi buroyi molochnoyi porodi ta vpliv genotipovih i paratipovih faktoriv na yiyi formuvannya [Peculiarities of milk productivity of Ukrainian brown dairy cows and influence of genotypic and paratypic factors on its formation]. Nauk. Vis.LNUVMB im. S. Z. Gzhickogo, issue 20, pp. 8-16. DOI: https://doi.org/ 10.32718/nvlvet8901.

7. Sklyarenko, Yu. I. and Chernyavska, T. O., 2018. Zmini vmistu skladovih moloka pri zahvoryuvanni koriv na mastit [Changes in the content of milk components in cows with mastitis]. Visnik Sumskogo nacionalnogo agrarnogo universitetu, issue 1(22), pp. 66-68.

8. Smolyar, V. I., 2011. Kompleks zahodiv z pidvishennya yakosti moloka [A set of measures to improve the quality of milk]. Visnik Dnipropetrovskogo, issue 2, pp. 151-155.

9. Tkachuk, V. P., 2011. Molochna produktivnist velikoyi rogatoyi hudobi ta faktori, sho yiyi viznachayut [Dairy productivity of cattle and factors that determine it]. Tehnologiya virobnictva i pererobki produkciyi tvarinnictva, issue 6, pp. 38- 41.

10. Fil, S. I., Fedorovich, Ye. I. and Bodnar, P. V. Molochna produktivnist koriv-dochok riznih bugayiv-plidnikiv [Dairy productivity of daughters of cows of different breeding bulls]. Nauk. Vis.LNUVMB im. S. Z. Gzhickogo, issue 21, pp. 68-75. DOl:https://doi.org/10.32718/nvlvet-a9012.

11. Carenko, O. M., Zlobin, Yu. A., Sklyar, V. G. and Panchenko, S. M., 2000 Komp'yuterni metodi v silskomu gospodarstvi ta biologiyi : navchalnij posibnik [Computer methods in agriculture and biology: a textbook]: Sumi: «Universitetska kniga».

12. Chumel, R. A., 2004. Genetic-biochemical and productive features of cattle in the north-eastern region of Ukraine. Abstract of Ph. D. dissertation, Chubinske, Kyiv region.

13. Bras, R., 2009. Milk quality of Jersey cows kept on winter pasture supplemented or not with concentrate. Revista Brasileira de Zootecnia, Issue 38, pp. 1983-1988. DOl:https://doi.org/10.1590/S1516-35982009001000018.

14. Dobson, H., Smith, R. F., Royal, M. D., Knight, C. H. and Sheldon, I. M., 2007. The high producing dairy cow and its reproductive performance. Reprod Domest Anim, Issue 42, pp. 17-23. DOl:https://doi.org/10.1111/j.1439-0531.2007.00906.x.

15. Evans, K., Rawlynce, C., Joshua, O. A. and Fidalis, D. N., 2018. Milk Composition for Admixed Dairy Cattle in Tanzania. Frontiers in Genetics, Issue 9, pp. 1-12. DOl:https://doi.org/10.3389/fgene.2018.00142.

16. Marchi, M, Bittante, G, Dal Zotto, R., Dalvit, C. and Cassandro, M., 2008. Effect of Holstein Friesian and Brown Swiss breeds on quality of milk and cheese, Issue 91(10), pp. 4092-102. DOl:https://10.3168/jds.2007-0788.

17. Marchi, M., Dal Zotto, R., Cassandro, M. and Bittante, G., 2007. Milk Coagulation Ability of Five Dairy Cattle Breeds. Journal of Dairy Science, issue 90 , pp. 3986-3992. DOI:https://doi.org/10.3168//js.2006-627.

18. Puppel, K., Bogusz, E. and Gołebiewski, M., 2017. Effect of Dairy Cow Crossbreeding on Selected Performance Traits and Quality of Milk in First Generation Crossbreds. Journal of Food Science, issue 83, pp. 229-237. DOl:https://doi.org/10.1111/1750$\underline{3841.13988 .}$.

19. Stocco, G., Cipolat-Gotet, C., Bobbo and T., Cecchinato, A., 2017. Breed of cow and herd productivity affect milk composition and modeling of coagulation, curd firming, and syneresis. Journal of Dairy Science, issue 100, pp.129-145. DOl:https://doi.org/10.3168/jds.2016-11662.

20. Yang, T. X., Li, H., Wang, F., Liu, X. L. and Li, Q. Y., 2013. Effect of Cattle Breeds on Milk Composition and Technological Characteristics in China. Asian-Australas J Anim Sci, 2013. issue 26(6), pp. 896-904. DOl:https:// doi.org/10.5713/ajas.2012.12677.

Chernyavska Tetyana Oleksiivna, PhD., Associate Professor, Sumy National Agrarian University (Sumy, Ukraine) Characteristics of qualitative composition of milk of cows of ukrainian brown dairy breed

The analysis of literature sources on the issue of breed characteristics of qualitative indicators of milk productivity of cows is carried out. Breed features concerning the content of separate components of milk are revealed. One of the important criteria for the quality of raw milk is the number of somatic cells in milk, given that they are a reliable indicator of cows' disease of mastitis. Therefore, to monitor the competitiveness of dairy farming requires regular monitoring of milk quality. This applies primarily to animals of domestic breeds, due to the small number of studies. The solution to this issue has led to research on the livestock of the Ukrainian brown dairy breed, which is kept in the State Enterprise "Experimental Farm agrofirm "Nadiya" of the Institute of Agriculture of the Northeast of the National Academy of Agrarian Sciences of Ukraine." The content of milk components was determined in the laboratory of the Institute of Animal Husbandry of the National Academy of Agrarian Sciences of Ukraine on Bentley equipment. We analyzed the qualitative characteristics of milk productivity of cows and found that animals of the Ukrainian brown dairy breed have a sufficient content of fat and protein in milk. The dependence of the content of milk components on the age of animals is revealed. Thus, adult animals had an advantage in terms of protein, casein, dry matter and dry nonfat milk residue over the first-born cows. The average content of somatic cells in milk corresponded to the physiological norm. It was found that with increasing age in cows increases the content of somatic cells in milk. The connection of different direction and level of reliability between separate qualitative indicators of milk is revealed. A positive relationship has been established between the content of fat and protein in milk, fat and dry matter, protein and casein, protein 
and dry skim milk residue. it has also been found that in adult animals the bond strength increases. A significant negative correlation was found between the number of somatic cells in milk and the content of dry nonfat milk residue and lactose. Further improvement of the Ukrainian brown dairy breed should be aimed at improving the quality of milk.

Key words: milk, breed, correlation, fat content, protein content, somatic cells.

Дата надходження до редакції: 27.10.2020 р. 